\title{
Can Secularism Hinder Democracy? The Turkish Experiment
}

\author{
Begüm Burak*
}

\begin{abstract}
The concept of democracy that has gained importance since the end of the Second World War and the relation between state and religion in Turkey have attracted a considerable degree of interest in various academic circles. It is known that in democratic systems, equality before the law and equality of opportunities for all individuals are regarded as integral elements. In this context, although it may be argued that many states that have a secular system are actually democratic in terms of their non-intervention in the religious choices of its citizens, it is also known that there is another interpretation of secularism in which the state exercises control over religion. The Turkish case represents a unique example in the study of the relationship between secularism and democracy with regard to the dominant role of the state in religious affairs. This study will attempt to analyze the negative impact of the state's interpretation of secularism on democracy in Turkey.
\end{abstract}

Keywords: Turkey, Modernization, Secularism, Laicism, Democracy, Kemalist Elitism.

Öz: İkinci Dünya Savaşı sonrasında önemi giderek artmış olan demokrasi kavramı ve din-devlet ilişkileri akademik çevrelerin önemli ölçüde dikkatini çekmektedir. Bilindiği üzere, demokratik niteliğe sahip siyasal sistemlerde, vatandaşların hukuk önünde eşit olması ve fırsat eşitliğine sahip olmaları gibi konular önemli bir yer tutmaktadır. Bu bağlamda, çoğu laik devletin, vatandaşlarının dini tercihlerine karışmaması noktasında demokratik bir karakter taşıdığı ileri sürülebilir. Buna karşın; dinin üstünde devlet denetimi anlamı taşıyan bir laiklik yorumu da mevcuttur. Bu bakımdan, Türkiye, laiklik-demokrasi ilişkisinde devlet kurumunun din üstündeki baskın rolüne ışık tutan bir örneği temsil etmektedir. Bu çalışma, Türkiye bağlamında, devletin laiklik yorumu ve laiklik pratiğinin, demokrasiye olan olumsuz etkilerini ele almaya çalışacaktır.

Anahtar Kelimeler: Türkiye, Modernleşme, Laiklik, Laisite, Demokrasi, Kemalist Elitism.

* Res. Assist., Fatih University, Department of Political Science and Public Administration, Correspondence: bburak@fatih.edu.tr, Fatih Üniversitesi, 34500, Büyükçekmece, İstanbul / Turkey Atıf(: Burak, B. (2012). Can secularism hinder democracy? The Turkish experiment. Insan \& Toplum, 2 (4), 65-82. 
"The Turkish Army is determined to defend the unitary secular state founded by Ataturk... Protection of fundamental characteristics of the republic cannot be considered as an intervention in domestic politics." "

Işık Koşaner, ex-Chief of the General Staff

\section{Introduction}

In the aftermath of the Turkish War of Independence, the Republic of Turkey was established from the ashes of the Ottoman Empire in 1923. The most prominent characteristic of the Turkish Republic since 1923 has been its adoption of a secular identity. In this context, it can be argued that, according to the founders of Turkey among whom Kemal Ataturk has an undisputedly decisive and dominant role, the most top priority was to turn Turkey into a modern, Western-oriented state with an acute secular character.

Indeed, the state elites ${ }^{2}$ and political elites in the early years of the Republic placed a special emphasis on the separation of state affairs from Islam. From their point of view, Islam meant backwardness and was considered to be an impediment against modernization. Therefore, in order to completely sever people's ties with their Ottoman past, religion had to be eliminated from the public sphere and take its place solely within the private lives of the masses.

In the early years of the Republic, the rapid, top-down process of modernization carried out paved the way for a considerable degree of secularization. The aspiration for adopting a Western type of social and political life further strengthened the secularizing reforms. The secularizing reforms, such as the abolition of religious colleges and high schools (medrese) and the creation of the Directorate of Religious Affairs (Diyanet) all helped the new regime place religion and its expression under its own control.

It is obvious that, the secularist drive was the most defining characteristic of the Kemalist reform movement (Zurcher, 2003, p. 186). Ironically, the way these reforms were implemented has impeded another important aim of the Kemalist modernization process: realizing a democratic political life. Becoming a modern state for the Kemalist elites meant having a Western style political and social life. Democracy was the foremost political system that would bring Turkey closer to Western civilization. However, until 1946, the Kemalist elites did not allow any political opposition to come

1 See Tait (2008).

2 I refer to appointed (not the elected) people by using the term 'state elites'. State elites comprise elements of the military and civilian bureaucrats and the judiciary. It should be noted that, the traditional state elite model in Turkey has been undergoing a transformation since the late 1990s. 
into-being in the form of a political party for example except for the experiences that took place in 1924 and 1930. Despite the fact that democracy had been an indispensable value in the West, elites in Turkey had thought that a top-down, state-led modernization process could not be accomplished democratically and so they adopted a single-party system reigning for several years.

On the other hand, secularism is seen by many people as being a core prerequisite in the constitution of a stable democracy (Stepan, 2000). In stable democracies, existence of different social, ethnic and religious groups are all welcome and the peaceful co-existence of such diverse elements can only be realized through a secular system (Husain, 2001). However, this view does not imply that all secular countries are democratic. ${ }^{3}$ It must be noted that a simply maintaining the separation between state and religion is not enough to establish democracy. In the Turkish case, the radical secularist understanding has led to the erosion of democratic norms by excluding certain groups of people from the public sphere.

The Turkish regime of the 1930s and 1940s whose main characteristic was a top-down manner of reform paved the way for not only the separation of state and religion but also for a strict state control over religion. In this paper, the state's view of secularism which used to dominate Turkish political life until the late $1990 \mathrm{~s}^{4}$ is brought into question. It is known that, under Turgut Özal's administration, a considerable degree of economic and political liberalization was witnessed and this experience has led to the erosion of the strict interpretation of secularism which was used to control and even oppress religious actors and religion-related issues. Under Özal rule, Islamic actors started to emerge in both economic and political arenas where they started to challenge secularist and non-liberal practices of the state. In 1999, moreover, when Turkey officially began its bid to enter the European Union, relations between the state and religion started to make a democratic turn.

In this study, by trying to explore the main determinants of the relationship between democracy and secularism, a critical point of view will be revealed in order to shed a light upon the Turkish case. The major argument of this study is that the state policies and practices toward religion constitute a major problem in the consolidation of democracy today, although a considerable degree of development has been achieved in order to make these practices more compatible with democratic procedures.

3 For instance, Syria is characterized as a secular state. It is not a democracy; it is a dictatorship that oppresses its own people.

4 In the years of the Ozal administration, Turkish political landscape has witnessed a relative degree of liberalization especially in the field of strict secular(ist) state view. However, it was not until the late 1990s (the time when the official EU candidacy of Turkey was accepted), that a considerable degree of liberalization in secular(ist) [laikçi] understanding took place. 
Turkey must have an appropriate balance between religion and secularism. It is noteworthy that, compared to past decades, Turkey has made a considerable amount of progress making its understanding of secularism understanding more harmonious with her democracy. In the previous decades, Turkey had adopted a specific kind of laicism that is the Kemalist understanding of laicism in its relationship with religion. This Kemalist understanding of laicism is both authoritarian and undemocratic.

It can be said that, Turkey which is the only secular and democratic country among Muslim majority countries offers an excellent example for those who seek answers to the following questions: Can Islam and democracy coexist? How far can religion and secularism be reconciled?

This paper's aim is to draw a theoretical framework of secularism. In addition, the study attempts to shed light upon the term of "laicism." Furthermore, this study aims to question the Turkish understanding of laicism and its impact upon democracy. This paper tries to shed light upon the historical evolution of secularism as well as to analyze different models of secularism. Secondly, this paper covers secularism in a mainly Turkish context. While doing so, a special emphasis has been given to the modernization process of Turkey because the origins of the relationship between state and Islam in Turkey today, date back to the early years of the Republic and also to a certain degree back to the late Ottoman period. Thirdly, this paper covers the nature of the relationship between democracy-secularism and laicism. Finally, this paper employs a critical approach in analyzing the Turkish case.

\section{Secularism and Laicism: Some Theoretical Considerations}

It is widely accepted that secularism advocates the separation of politics from religion. Broadly, there are two kinds of separations. The first identifies separation with exclusion. For the second, to separate is to create distance or to delineate certain boundaries between the two (Raz, 1986, p. 109). The secular state, in a sense, must be anti-religious. This antireligiosity may be either interventionist or non-interventionist. In its interventionist form, the state actively discourages religion, which is known as 'laicism'.

On the other hand, the most common definition of secularism is the separation of religion from state affairs in which the state does not encompass many important characteristics of a religious government. A secular government is neutral towards all religions (Quoted in Wing and Varol, 2005, p. 6). Burayı ben kırmızı yapmadım. As such, the government cannot claim an official religion and does not protect one religion at the expense of another. Likewise, all individuals, irrespective of their religion, are equal before the law (Ibid). For a leading scholar of secularism, Talal Asad, secularism 'is an enactment by which a political medium (representation of citizenship) redefines 
and transcends particular and differentiating practices of the self that are articulated through class, gender and religion' (Cited in Bangstad, 2009, p. 190).

Moreover, a secular regime requires the education and the legal systems to be tolerant toward different religious orientations while at the same time not containing laws based on any particular religion. In addition, a secular government requires freedom of religion and conscience, thus, secularism does not entail the absence of religion from society. Individuals are free to exercise their religions and manifest their religious beliefs in both the private and the public spheres. A secular state cannot place limitations upon the citizens' religious activities. Despite having laws which do not depend on religion, a secular state cannot monopolize the public sphere within a secularist understanding that excludes religion. Finally, a secular regime is based on pluralism, which requires the government to respect all religions and religious beliefs. It is important to note that the foregoing characteristics describe a theoretically perfect secular government, which does not exist (Bangstad, 2009)

Secularism has its origins in Western Europe which occurred along with the rise of capitalism and nation-states. The rise of nationalism also stimulated secularism. Several intellectuals encouraged secularism in their writings while advocating religious tolerance, like John Locke's A Letter Concerning Toleration (1689) and John Stuart Mill's On Liberty (1859). Enlightenment writers often stressed anticlericalism and attacked the Catholic Church. Apart from this, industrialization, urbanization, and the rising role of different economic class groups helped undermine religious ties and promote secularism (Holyoake, 1898).

Secularism cannot be evaluated as a monolithic practice or world view. There are different models of secularism. ${ }^{5}$ For instance, the French model is understood as 'assertive secularism' which addresses the subjection of religion to the state. By contrast, the American model is considered 'passive secularism' which addresses the autonomy of religion from the state. Passive secularism implies that the state maintains neutrality toward various religions and allows their public visibility. Assertive secularism, on the other hand, means that the state favors a secular worldview in the public sphere and aims to confine religion to the private sphere.

Laicism and secularism refer to two different ways of how to organize the relationship between state and religion. These concepts are, in a limited sense, similar to one another as they both include two mutual elements: (1) a separation between state and religion (separation of political authority from religious authority) and (2) freedom of religion. It is the visible appearance of religion that demarcates the difference between the two.. Secularism is usually described as being more tolerant toward the 
public visibility of religion; a secular and democratic state plays a passive role and allows religious symbols to exist within the public domain. By contrast, in laicism, the state plays a more active role by actively excluding religious symbols from the public domain and thus confines religion to the private domain (Tarhan, 2011, p. 1).

Laicism or laïcité in French is usually defined as a unique feature of French political culture. It emerged after the 1789 Revolution as a way of separating state and religion (Ibid). In the laicist understanding, the religion has no autonomy; on the contrary it is to be put under strict control of state authority.

\section{State-Religion Relationship and Democracy}

Since the end of the Second World War, democracy has been the most prominent political system in world politics. Democracy is much broader than a being a special political form, a method of conducting government, of making laws, and effectuating governmental administration by means of popular suffrage and elected officers.

Before answering this question, it must be understood that democracy cannot be identified solely with majority rule. Democracy has complex demands, which certainly do include voting and respect for election results, but it also requires the protection of liberties and rights, respect for legal entitlements, and the guaranteeing of free discussion and uncensored distribution of news and fair comment. Elections themselves can even be deeply defective if they occur without the different sides receiving an adequate opportunity to present their respective cases or without the electorate enjoying the freedom to obtain news and to consider the views of the competing candidates. Democracy is a demanding system, and not just a mechanical condition, like majority rule, taken in isolation (Sen, 2011).

Robert Dahl (1982) has offered the most generally accepted list of what he terms the "procedural minimal" conditions that must be present for modem political democracy, or as he puts it, "polyarchy," to exist:

1) Control over government decisions regarding policy is constitutionally vested in elected officials.

2) Elected officials are chosen in frequent and fairly conducted elections in which coercion is comparatively uncommon.

3) Practically all adults have the right to vote in the election of officials.

4) Practically all adults have the right to run for elective offices in the government.

5) Citizens have a right to express themselves without the danger of severe punishment on political matters broadly defined. 
6) Citizens have a right to seek out alternative sources of information. Moreover, alternative sources of information exist and are protected by law.

7) Citizens also have the right to form relatively independent associations or organizations, including independent political parties and interest groups.

The nature of the relationship between secularism and democracy largely depends on the practices in which the state involves itself. As noted above, in some countries, state control over religion is witnessed; whereas in others, a neutral attitude is adopted toward religion giving it an autonomous space. Hence, it could be stated that state intervention in religious issues and the religious realm paves the way for the subjection of religion which can be regarded as an obstacle against democratically-driven state-society relations. On the contrary, the separation of state and religion which addresses the autonomy of religion leads to a more liberal and plural society which, in the end, empowers democratic processes.

On the other hand, government involvement in religion undermines citizen equality by favoring certain religious views over others. It is believed that the separation of religion and state is a critical component of democracy, since lacking such a separation erodes equality within the polity, thereby damaging the foundation of democracy and which, in turn, decreases levels of democracy (Brathwaite, 2011, p. 235).

It is widely accepted that, at the core of democratic political culture, there lies tolerance toward different world views and a respect for human rights (Çakır, 2002). In a democratic state, the political authority does not impose a set of behaviors on the public. In other words, democracies are the political systems wherein people may freely make their own choices about what kind of life they will lead: be it a religion-based one or not. In this context, the form of secularism seen in the Anglo-Saxon model, which highlights the autonomy of religion, paves the way for a democratic system. On the contrary, the French model - laicism - puts religion under pressure and does not reserve its right of autonomy, thereby also undermining democracy.

\section{Secularism or Authoritarianism? The Case of Turkey}

In order to analyze the basic dynamics of secularism and the relationship of state and religion in Turkey, an overview must be made regarding the modernization process Turkey underwent. There exists an overwhelming consensus among scholars of modern Turkey that Turkish modernization and its nation-building process has largely been topdown, state-led, and elitist. Hence, its characterization is seen as a "project" rather than a "process," the latter implying a societally-generated movement (Vaxman, 2000, p. 5).

The Turkish modernization experience is generally dated to have begun in the $1800 \mathrm{~s}$ (Tanzimat Era). In this era, the first signs of a secular understanding were witnessed. 
The purpose of the reforms carried out during the Tanzimat years was to meet the demands of the propertied classes for legal protection; it meant equality for all citizens and the codification of penal and commercial laws. More significantly, the Sultan was to reorganize his bureaucracy in compliance with the imperatives of an "independent" and "rational" society (Unat, 1979, p. 4).

On the other hand, the Young Turks who gained political power in 1908 through a military coup played a major role in affecting the state attitude toward religion, as many of the key actors in this group held positivist tendencies. After the foundation of the Turkish Republic, the modernization project was carried out most heavily by the Turkish Army. It must be remembered that the first efforts of modernization had begun in the military sphere during the Ottoman era. The modernization of the army was seen as being the creation of a European style army in terms of education, technology, and structure. As a natural result of these efforts, Western values and norms first entered Turkish society via the military elites (Arslan, 2000, p. 2). It must also be stated that the Turkish army has seen itself as the sole protector of the secular Turkish Republic.

During the one-party era, the reform policies between the years 1925-1935 aimed to secularize state bureaucracy, education, and law (Zurcher, 2003, p. 186). The secularization of social life was also realized. For the founding fathers of modern Turkey, cultural change was the key to modernization. For Mustafa Kemal and his associates, the role of Islam in Ottoman society and politics was responsible for the failure to modernize (Toprak, n.d.).

The most significant step in the secularization of social life was the suppression of the dervish orders (tarikat) announced in September and put into operation in November 1925. These mystical brotherhoods had served vital religious and social functions throughout Ottoman history (Zurcher, 2003, p. 191).

By extending their secularization drive beyond formal, institutionalized Islam, the Kemalist elites also attacked vital elements of popular Islam, such as dress, amulets, holy sheikhs, pilgrimages, and festivals. It must be noted that, while the government succeeded in suppressing most expressions of popular religion, towns and the country side were able to escape, at least partially, from the effects of such reforms that envisioned the complete disappearance of popular religion (Zurcher, 2003, p. 192).

Secularization reforms, which were undertaken during the first decade of the new republic, founded in 1923, aimed at minimizing the role of religion in every walk of Turkish society. The motive behind the strict secularization program was to reduce the societal significance of religious values and to eventually disestablish cultural and political institutions stamped by Islam (Küçükcan, 2003, p. 486). 
Indeed, in the eyes of many observers of the Turkish Republic, both past and present, Kemalism was hostile to Islam and sought to replace the religious identification hitherto prevalent in the Turkish population with a national identification. Perceiving Islam as a reactionary and potentially threatening force which could obstruct modernization and nation-building which they envisaged for the new Turkish Republic, the Kemalists allegedly sought to banish Islam from the public sphere and displace it in the private sphere through an attachment to secular Turkish nationalism (Vaxman, 2000, p .8).

The early reforms of the republic targeted the role of Islam in politics and administration. The Caliphate, an important institution symbolizing the unity of all Muslims throughout the world, was abolished. All religious schools were banned and the educational system was unified under a newly established Ministry of Education. Orthodox Islam was put under state control through the creation of a Directorate of Religious Affairs (Toprak, n.d.).

However, despite the secularization efforts and the restrictions on religious practices, Islam has remained as one of the major identity references in Turkey and it continues to be an effective social reality, shaping the fabric of Turkish society (Küçükcan, 2003, p. 490). On the other hand, Turkey's transition into multi-party politics marked a turning point in relaxing the official attitude toward religion, thus ending the era of radical secularism - in other words laicism - set forth by the Republican People's Party (CHP).

It is known that the Democrat Party government, which came to power after the first elections were introduced in the multi-party era, took steps in strengthening the role of religion in both private and public spheres. For example, the DP administration allowed the building of new mosques, extended religious education as well as allowing Islamic radio programs. Furthermore, the call to Prayer (ezan) began to be again called in Arabic instead of Turkish.

The tolerant behavior of the DP leaders toward religious actors immediately alarmed the military elites who saw themselves as the only protector of the secular Republican regime. As the central institution in the foundation and modernization of Turkey, the Turkish Army did not hesitate to intervene in 1960. The foremost justification of the military coup ${ }^{6}$ was that the DP government had politicized Islam and had therefore abused it as a tool in daily politics. In addition, the secular character of the state was considered to be under serious attack by so-called Islamist policies.

In the following years, the military elites continued to exercise direct and indirect interventions in politics. However, these interventions are out of the boundaries of the current scope of this study. It must be said that, most of the time, the military elites saw Islamist societal movements and political parties as a threat to secularism and marked 
them as an "internal enemy," The most obvious example of this was seen in the February 28 Process in 1997, ${ }^{7}$ when an Islamist-led government was forced to resign by the military and the military-led "civilian" actors, such as the mainstream media.

\section{Anti-Secular Provisions in the Turkish Constitution?}

There are two provisions in the Turkish Constitution that some commentators view as inconsistent with the principles of secularism. The first one revolves around the existence of the Department of Religious Affairs. Article 136 of the 1982 Constitution establishes a Department of Religious Affairs ${ }^{8}$ (Diyanet Isleri Baskanligi) within the general administration. The employees of the Department are civil servants, and its funds are appropriated from the administration's budget. The Department is responsible for the regulation of the religious life of all Muslims living within the country. Among other things, the Department of Religious Affairs appoints religious officials, including imams, pays the stipends of religious officials, and directs the administration of more than 70,000 mosques.

According to Article 136 of the Constitution, the Department of Religious Affairs has to exercise its duties in accordance with the principle of secularism, removed from all political views and ideas (Turkish Constitution of 1982, Article 136). It must also be noted that, the Department of Religious Affairs promotes the orthodox understanding of Islam prevalent in Turkey, namely Sunni Islam. However there are many people who consider themselves to be members of Alevism, another sect in Islam outside of the orthodox Sunnism practiced in Turkey. Because of the official state policy which excludes the Alevi identity, the Alevi citizens in Turkey feel marginalized and alienated. This marginalization considerably undermines democracy.

Another controversial provision in the Turkish Constitution deals with mandatory religious education. Article 24 states:

Education and instruction in religion and ethics shall be conducted under state supervision and control. Instruction in religious culture and moral education shall be compulsory in the curricula of primary and secondary schools (Turkish Constitution of 1982, Article 24).

Mandatory religious education undermines the principle of "equality of opportunities" because the children of citizens who do not consider themselves to be Sunni Muslims are forced to take courses based on this specific interpretation of Islam which seems to be both illiberal and incompatible with democracy.

7 For a detailed study about this process, see Burak (2010).

8 Some groups, particularly Alevis, whose belief system incorporates aspects of Shi'a and Sunni Islam and also draws on the traditions of other religions found in Anatolia, claim that Diyanet only reflects the mainstream Sunni Islamic belief and excludes other beliefs (World Movement for Democracy, n.d). 


\section{The Headscarf Ban}

The wearing of the Islamic headscarf at Turkish universities is a relatively recent phenomenon, which started in the 1980s and subsequently led to the adoption of various regulations and legislation related to the issue (Wing, \& Varol, 2005, p. 36). The Cabinet issued the first regulation addressing the wearing of Islamic headscarves in universities in 1981. The regulation required staff working for public organizations and institutions as well as personnel and students at state institutions to wear ordinary, sober, modern dress. The regulations also provided that female members of staff and students should not wear headscarf in educational institutions (Wing, \& Varol, 2005).

Indeed, the most dramatic and noteworthy developments relating to the headscarf issue have been witnessed during the February 28 Process in 1997. During that time, all people who were characterized as being pious were seen as "internal enemies" by state elites. The boundaries of the public sphere which were determined through Kemalist elitism did not allow them to take part in the public sphere. For instance, many academics, teachers, and other personnel in other areas who worked in public places lost their jobs simply because of their religious identities.

Women who lost their jobs or were expelled from school due to wearing headscarves during the days of the February 28, 1997 military coup have since filed criminal complaints against the perpetrators of the intervention:

One of the women, Hüda Kaya, who along with her daughters was accused in court of 'attempting to forcefully dissolve the Turkish Republic,' a charge based on wearing headscarves carrying a possible death sentence when it was laid against them in 1999, said: 'We would like to see those who limited people's right to work and receive education during the Feb. 28 process stand trial. These cases [against coup perpetrators] should not just be opened. We want to see their conclusions. Despite positive developments, headscarf-wearing people are still not [allowed to participate] in all walks of life.' (World Bulletin, 2012).

On the other hand, a plethora of legal regulations have been adopted, some banning the headscarf, others lifting the ban. Over the course of time, this issue has become a central point of concern within the debate of secularism and its role in Turkey. Some find the ban on headscarves to be incompatible with secularism while others would disagree. Apart from this, in the past the entire bureaucratic system was dominated by people who held a strict secular understanding and lifestyle. It is normal now, however, to see someone in the bureaucracy whose wife wears a headscarf (Akyol, 2007).

\section{What is Going On Today?}

In the aftermath of the 2002 elections, the Justice and Development Party (JDP) - AK Party - whose important actors consider themselves to be pious as well as being treat- 
ed as religious political figures of the time-being, came into power and still administers the country with a majority government. A number of individuals with ultra-secularist views today hold fears that the party has a secret agenda to turn Turkey into an Islamic state (Baran, 2008, p. 59). However, it is obvious that the most important steps taken in attaining European Union membership have been taken during the JDP administration. These steps have covered further democratization along with liberalization and cannot be viewed as anti-secularist movements in and of themselves.

According to a leading scholar, Binnaz Toprak, secularism in Turkey served not to separate religion and politics (as in the 'Western' model of separation of church and state) but to control religion. This was because, as Toprak wrote:

Religion in Turkey, especially during the formative years of the Republic, had been the most important centrifugal force with a potential to challenge the state. It is partly for this reason that the separation of religion and state was never attempted in its Western version as Orthodox Islam was put under state control and made subservient to state authority (Toprak, 1988, pp. 119-136).

It must be stated that, despite its changing strategy toward Islam, one of the most enduring features of the Turkish state has been the way it has continuously maintained control over Islam (Sakallığlu, 1996, p. 248). Despite official state secularism however, Islam is deeply engrained in Turkish culture. This becomes obvious when traveling through the country, where one sees a constant display of mosque minarets in most neighborhoods and the many women wearing traditional Muslim dress - both of which are also visible in even the most modern parts of Turkish cities (Atlas, 2008). It has also been argued that:

From the perspective of secularism, the attitude of the state towards religion, it is obvious that there has not been a monolithic, uniform or linear pattern. This may be due to the fact that different interests, power groups, elite, and segments within the state have their different agendas, visions and ideas with regard to role of Islam within society, if not within politics. From time to time, the emphasis of the state on this role of Islam changes in accordance with conjecture, socio-politics and geo-politics (Yılmaz, 2005, p. 386).

On the other hand, the diversity of meanings attached to the term secularism by different actors of Turkey (such as politicians and the military) shows how differently the relationship between democracy and secularism is regarded. For example, according to the current Prime Minister, Recep Tayyip Erdogan:

"Secularism must not have a decomposing character but it must be unifying... the principle of secularism must not function as a stimulator that bans individual liberties with an illiberal world view. This would contradict with the the democratic and modern soul of Turkey." ("Devletin zirvesinin laiklik tanımları," [The secularism definitions of state top officials] 2011). 
In parallel, President Abdullah Gul defines secularism as "a state behavior that respects all kinds of faith systems and religions while taking an equal distance towards each religion and faith system." Gul argues that "the principle of secularism exists for providing liberty for the citizens to be able to feel free to choose in what to believe." ("Devletin zirvesinin laiklik tanımları," [The secularism definitions of state top officials] 2011).

According to a distinguished scholar of Turkish politics, Mumtaz'er Turkone, the principle of secularism is defined as a sort of positivism by one of the ex-heads of the Army, llker Basbug. Turkone emphasizes that the Army sees itself as the sole guardian of secularism. He further argues that the definition of secularism must not be made by the military. Instead, the judiciary must define it (Türköne, 2006).

The Turkish Armed Forces states that:

Religion is a matter of conscience. Everyone is free to obey the order of their conscience. We respect religion. We are not against free thinking and ideas. We just aim to ensure that matters of religion do not interfere with issues of the state and nation.

In addition, the Army says that "Everyone in the Turkish Republic can worship their deities as they wish. Nobody can intervene into any other's life because of his/her religious beliefs. The Turkish Republic has no official religion." (Turkish Armed Forces, n.d.) It must be stated that, what is experienced regarding state and religion relations are not as clear in Turkey as the official documents or state elites put forward. For instance, a recent debate about Cemevleri9 ${ }^{9}$ shows the pathological state practices. The Supreme Court of Appeals has declared that Cemevleri cannot be given the status of place of worship and the Court used the Revolution Reforms as the basis for its decision (Cemevlerine 'tekke ve zaviye' içtihadı," 2012). With this decision, the state mechanism (the judiciary) has intervened into the sphere of religion and not acted in a neutral position. Some of the state elites justify this position; according to a chief prosecutor: "Since the natures of the Christian and Islamic religions are different, the implication of secularism in the West and in our country has been different." (Akyol, 2012).

In reality, the Turkish case presents a different example in state-religion relationship as noted above. It can be said that, the legal/constitutional dimension of that relationship plays a key role in revealing that difference. In Turkey, secularism is seen not as the separation of religion and state but it rather focuses on the supposed rights of the state to curb religion in public life as seen in the case of laicism.

On the other hand, during the 1980s, Islam was treated as a counter-instrument against communism and for that reason, mandatory religious courses came into-being 
while the number of the vocational religious high schools increased (Narlı, 1999, p. 39). However, in 1997, after the post-modern coup, state behavior was turned upside down and religion and pious citizens were seen as threats. These single examples show that Turkey has a self-styled secularism and which therefore impedes democratic consolidation.

Apart from this, the secular(ist) understanding in Turkey, which has strongly been shaped by Kemalist elitism, hinders the very pluralism that is a key component of liberal democracy. According to Ahmet Kuru, a leading scholar, ideological and anti-religious meanings have been attached to the principle of secularism which undermines democratic consolidation in Turkey (Gündem, 2009). Kuru argues that the assertive secularism seen in France and similarly in Turkey has fed itself with supposed fear and he states that the "imagined" probability of Turkey's becoming an Islamic state has been feeding this interpretation. Another statement of Kuru signifies that the assertive secularism in Turkey, which has dominated the political and social lives between 1930 s and 1950s and again since the mid-1980s, has now begun to turn into some kind of passive secularism.

Today, the JDP and other rightist parties, which represent nearly 70 percent of the voting population, have by and large supported Turkey's leaning toward passive secularism. In January 2004, in a press conference in Washington, DC, Erdogan stressed his desire to reinterpret Turkish secularism by analyzing the American model ("Türkiye'deki laiklik İslam dünyasına model olabilir mi?," 2004).

In short, it can be said that, the Turkish experiment in analyzing the nature of relationship between secularism and democracy presents a unique example. The reasons for that can be seen in the mandatory religious education and the existence of the Directorate of Religious Affairs. Unlike as seen in the West, there is no separation of state and religion separation is existent in Turkey. By contrast, state intervention in religious affairs is obvious. In this sense, secularism took the form of 'laicism', a concept that indicates not only the 'official disestablishment of religion' from the state, but also the 'constitutional control of religious affairs' by the state (Keyman, 2007, p. 222). This state policy toward Islam has unfortunately eroded democratic consolidation in Turkey.

\section{Concluding Remarks}

In contemporary Turkey, it is almost impossible to put forward an opinion about the nature of the relationship between secularism and democracy without making references to Turkey's top-down, state-led modernization experience. It could be said that Turkey continues to modernize and further democratize with a more stable economic 
structure thanks to the crisis of legitimacy the top-down, state-led understanding of modernity has undergone. It has been observed that laicism in Turkey has not, in fact, promoted secularism in Turkish society. It rather opts for the placing of religion under the sole authority of the state apparatus and excluding particular groups in the society.

It must be noted that since the 1990s, with the liberalization policies carried out by Turgut Özal's administration, a considerable amount of change has been achieved in terms of making politics become more inclusionary and making society become more plural. With Özal, the economic structure of Turkey started to become enriched through the emergence of conservative (and also religious) business organizations. The case of MUSIAD is a good example. The emergence of such organizations challenges the top-down implemented secularist understanding as members of such organization are religious people who have been educated according to Western standards.

The Turkish experiment with democracy has been interrupted by military interventions and to an important degree, these interventions have occurred because of the so-called "politicization of Islam." These experiences also reveal the fact that the Turkish type of secularism makes democracy rather fragile. Through excluding certain segments of society and treating them as "second-class citizens," state elites pave the way for the marginalization of some particular groups in society, such as the Alevis or head-scarf wearing women. Such exclusionary attitudes, which mainly derive from Kemalist elitism, must be eliminated in order to strengthen Turkish democracy and to make politics and society more plural and liberal.

Apart from this, it is known that the perception of religion by the Turkish Republic is based on a Sunni understanding. In other words, the Directorate of Religious Affairs and the mandatory religious education all serve Sunni Islam. As such, another major sect in Islam, namely Alevism, is excluded by public authorities. This is also a contradicting practice with the definition of secularism as noted above. In the case of Turkey, the state does not adopt an equal position toward each religion, or in this case, sect of the same religion, but instead favors Sunni Islam. Such behavior, in this context, cannot be viewed as a compatible practice with the principles of secularism. Here, it could be argued that the norm of equal citizenship, an important element of democracy, remains unheeded. It must be noted that a democratic constitutional state committed to human rights must make sure not to discriminate against any religion or attempt to assimilate particular religious groups, as is the current case in Turkey.

On the other hand, although the Turkish Constitution recognizes freedom of religion for individuals, religious communities are placed under the protection, and regulation, of state authority. Yet while doing this, the constitution explicitly states that such religious individuals cannot involve themselves in the political process (by forming a religious party for instance) and that no party may claim that it represents any form of 
religious belief. Nevertheless, religious sensibilities are generally represented through conservative parties. Paradoxically, these parties have most often been closed down by the Constitutional Court due to their supposed "anti-secular" tendencies.

In short, it can be said that the historical background of Turkey, along with its topdown implementation of cultural reforms and the aspiration of the founders of modern Turkey for breaking all ties with the Ottoman past have paved the way for the adoption of a strict secular(ist) [laikçi] understanding in Turkey. This understanding has so far neglected the religion-oriented pluralism in society and acted as a driving force in undermining democratic processes in Turkey. However, it must also be noted that since the late 1990s, this strict interpretation of secularism has been challenged to a great degree which may be seen as positive for the continued sustenance of democracy in Turkey.

\section{References}

Akyol, M. (2007, May 25). Turkey's political battle: Secularism vs. democracy. Retrieved on August, 22, 2011, from http://www.cfr.org/turkey/turkeys-political-battle-secularism-versus-democracy-rush-transcript-federal-news-service/p13666.

Akyol, M. (2010, October 22). Who knows what secularism is. Hurriyet Daily News. Retrieved August 2, 2012, from http://www.hurriyetdailynews.com/default.aspx?pageid=438\&n=who-knows-what-secularism-is-2010-10-22.

Arslan A. (2000). A different modernization experience: Turkish modernization and the army. Uluslararası Insan Bilimleri Dergisi, 1(2), 1-25.

Atlas, P. (2008, June 15). Secularism vs democracy in Turkey. Real Clear Politics. Retrieved August 22, 2011, from http://www.realclearpolitics.com/articles/2008/06/secularism_vs_democracy_in_tur.html.

Bangstad, S. (2009). Contesting secularism/s: Secularism and Islam in the works of Talal Asad. Anthropological Theory, 9(2),188-208.

Baran, Z. (2008). Turkey divided. Journal of Democracy, 19(1), 55-69.

Brathwaite, R., \& Bramsen, A. (2011). Reconceptualizing church and state: A theoretical and empirical analysis of the impact of separation of religion and state on democracy. Politics and Religion, 4, 229-263.

Burak, B. (2010). Türkiye'nin siyasal ve yönetsel yaşamında 28 şubat Süreci'nin yeri üzerine bir inceleme. Yayımlanmamış yüksek lisans tezi, İstanbul Üniversitesi, Sosyal Bilimler Enstitüsü, İstanbul. http://fatih.academia.edu/BegumBurak/Papers/441296/The_February_28_Process_in_Turkish_Political_and_Administrative_Life adresinden 22 Ağustos 2011 tarihinde edinilmiştir.

Burak, B. (2012). Turkey's unique mix of demoracy and laicism. Retrieved November, 5, 2012, from http:// www.dimpool.com/2012/07/begum-burak-turkey-unique-mix-of-democracy-and-laicism/

Çakır, N. (2002). Demokrasi ve laiklik açısından devlet-toplum ikilemi ve şeair kavramı. Köprü Dergisi, 80. http://www.koprudergisi.com/index.asp?Bolum=EskiSayilar\&Goster=Yazi\&YaziNo=83 adresinden 22 Ağustos 2011 tarihinde edinilmiştir.

Cemevlerine 'tekke ve zaviye' içtihadı. (2012, July 26). Radikal. http://www.radikal.com.tr/Radikal.aspx? aType=RadikalEklerDetayV3\&ArticlelD=1095275\&Category|D=77 adresinden 2 Ağustos 2012 tarihinde edinilmiştir. 
Dahl, R. (1982). Polyarchy. New Haven: Yale University Press.

Devletin zirvesinin laiklik tanımları [The secularism definitions of state top officials]. (2011, 6 Şubat). Sabah. http://www.sabah.com.tr/Gundem/2011/02/06/devletin_zirvesinin_laiklik_tanimlari adresinden 25 Ağustos 2011 tarihinde edinilmiştir.

Gündem, M. (2009, 12 Eylül). Ahmet Kuru: Türkiye 'çoğulcu laiklik'le rahatlar [A. Kuru ile röportaj]. Yeni Şafak. http://yenisafak.com.tr/roportaj/?t=01.09.2011\&i=216306 adresinden 4 Eylül 2011 tarihinde edinilmiştir.

Holyoake, G. (1898). The origin and nature of secularism. London: Watts \& Co.

Husain, Z. (2001, March 25). Secularism, democracy \& political morality [memorial lecture]. Retrieved July 31, 2012, from http://cpim.org/content/secularism-democracy-political-morality.

Keyman, F. (2007). Modernity, secularism and Islam: The case of Turkey. Theory Culture Society, 24(2), 215-234.

Küçükcan, T. (2003). State, Islam, and religious liberty in modern Turkey: Reconfiguration of religion in the Public Sphere. Brigham Young University Law Review, 1, 470-497.

Kuru, A. (2007). Passive and assertive secularism: Historical conditions, ideological struggles, and state policies toward religion. World Politics, 59(4), 568-594.

Locke, J. (1689). An essay concerning human understanding (revised editions: 1694-1700). London: Wlliam Tegg.

Mill, J. S. (1859). On liberty. London: J. W. Parker and Son.

Narlı, N. (1999). The rise of the Islamist movement in Turkey. Middle East Review of International Affairs, 3(3), 38-48.

Raz, J. (1986). The morality of freedom. Oxford: Clarendon Press.

Sakallıoğlu, U. (1996). Parameters and strategies of Islam-state interaction in Republican Turkey. International Journal of Middle East Studies, 28(2), 231-251.

Sen, A. K. (1999). Democracy as a universal value. Journal of Democracy, 10(3), 3-17. Retrieved August 10, 2011, from http://muse.jhu.edu/journals/jod/v010/10.3sen.html.

Stepan, A. (2000, October). Religion, democracy, and the "twin tolerations". Journal of Democracy, 11(4), 37-57. Retrieved July 31, 2012, from http://muse.jhu.edu/journals/journal_of_democracy/ v011/11.4stepan.html.

Tait, R. (2008, August 29). Turkish military will defend secular state, government warned. The Guardian. Retrieved August 26, 2011, from http://www.guardian.co.uk/world/2008/aug/29/turkey.islam.

Tarhan, G. (2011). Roots of the headscarf debate: Laicism and secularism in France and Turkey. Journal of Political Inquiry, 4, 1-17.

Toprak, B. (1988). The state, politics, and religion in Turkey. In M. Heper \& A. Evin (Eds.), State, democracy and the military: Turkey in the 1980s. (pp. 119-136). Berlin: Walter de Gruyter.

Toprak, B. (n.d.) Secularism and Islam: The building of modern Turkey. Macalester International, 14. Retrieved November 5, 2012, from http://digitalcommons.macalester.edu/cgi/viewcontent.cgi?article $=1391 \&$ context $=$ macint $\mid \&$ seiredir=1\&referer=http\%3A\%2F\%2Fwww.google.com.tr\%2Furl\%3Fsa\%3Dt $\% 26 r c t \% 3 D j \% 26 q \% 3$.

Turkish Armed Forces. Retrieved August 25, 2011, from http://www.tsk.tr/eng/Anitkabir/laik.html.

Turkish Constitution of 1982, Articles 136 and 24. Retrieved January 18, 2013 from http://www.anayasa. gov.tr/images/loaded/pdf_dosyalari/THE_CONSTITUTION_OF_THE_REPUBLIC_OF_TURKEY.pdf 
Türkiye'deki laiklik İslam dünyasına model olabilir mi? [Can Secularism in Turkey Be a Model for the Islamic World?]. (2004, 25 Nisan). Hürriyet

Türköne, M. (2006, 28 Eylül). Askeri ve hukuki laiklik [Military and legal secularism]. Zaman. http://www. zaman.com.tr/yazar.do?yazino=430680 adresinden 25 Ağustos 2011 tarihinde edinilmiştir.

Unat, N. (1979). Patterns of political modernization and Turkish democracy. The Turkish Yearbook, 9, $1-27$.

Vaxman, D. (2000). Islam and Turkish national identity: A reappraisal. The Turkish Yearbook, 30, 1-17.

Weiker, W. (1963). The Turkish 1960-1961 revolution: Aspects of military politics. Washington: Brookings.

Wing, A, \& Varol, O. (2005). Is secularism possible in a majority-Muslim country?: The Turkish example. Texas International Law of Journal, 42(1), 1-54.

World Bulletin. (2012, October 9). Victims of Turkey scarf ban file complaints against Feb. 28 actors. Retrieved November 5, 2012, from http://www.worldbulletin.net/?aType=haberYazdir\&ArticleID=968 $81 \&$ tip $=$

World Movement for Democracy. (n.d.) Human rights \& democracy in Turkey. Retrieved August 2, 2012, from http://www.wmd.org/resources/whats-being-done/human-rights-democracy-turkey.

Yılmaz, I. (2005). State, law, civil society and Islam in contemporary Turkey. The Muslim World, 95, 385411.

Zurcher, E. J. (2003). Turkey, a modern history. London: Tauris. 